\title{
Zooplankton Communities in the Bristol Channel and Severn Estuary
}

\author{
N. R. Collins and R. Williams
}

Natural Environment Research Council, Institute for Marine Environmental Research, Prospect Place, The Hoe, Plymouth PLI 3DH, Devon, England

\begin{abstract}
Zooplankton distributions in the Bristol Channel and Severn Estuary, for January, April and August 1974, were analysed using an hierarchical clustering technique (CLUSTER) and an ordination technique (multi-dimensional scaling). Shade-matrices were used to associate the groups of species with the groups of sampling sites derived from these techniques. Four groups of species or assemblages of zooplankton were described; these were numerically dominated by the calanoid copepods Eurytemora affinis (Poppe), Acartia bifilosa var. inermis Rose, Centropages hamatus (Lilljeborg) and Calanus helgolandicus (Claus), respectively. These 4 assemblages conformed to the generalised classification of plankton according to salinity in estuaries: true estuarine, estuarine and marine, euryhaline marine, and stenohaline marine. The groups were relatively consistent over the $3 \mathrm{mo}$, chosen to represent the seasonal features of a time series extending from November 1973 to February 1975. A strong relationship between the assemblages and salinity was demonstrated. It is suggested that these assemblages conformed to a working definition of a community.
\end{abstract}

\section{INTRODUCTION}

Recently there has been renewed interest and debate on whether the mechanisms determining the presence of groups or assemblages of species in particular environments are deterministic or probabilistic in nature (Williams et al., 1981). In some ways this is a consequence of recent reviews of plant communities by Shimwell (1977) and Whittaker (1978) and of the increasing use of multivariate analysis techniques to further the understanding of structure in plant and animal groups or 'communities' (Field et al, in press). Multivariate techniques have been used widely in ecology for the analysis of community structure. The faunas of more stable marine habitats such as the benthos have been studied using numerical analyses to identify patterns of species composition (Day et al., 1971; Field, 1971; Santos and Simon, 1974; Bloom et al., 1977), and the sublittoral macrofauna communities of the Bristol Channel and Severn Estuary (U. K.) have been investigated using these techniques by Warwick and Davies (1977).

The purpose of this work is to apply numerical analysis techniques to the distribution of zooplankton in the Bristol Channel and Severn Estuary, in an attempt to identify communities within the zooplank- ton. The communities will be related to salinity, the most important environmental variable affecting geographical distributions of plankton in estuaries, and the reality of communities as ecological units will be briefly discussed.

\section{METHODS}

Eleven surveys covered the period November 1973 to February 1975 (Collins and Williams, 1981) and the data from 3 of these, January (winter), April (spring) and August (late summer) have been selected to illustrate the main seasonal features of the distribution and abundance of the zooplankton in the Outer Severn Estuary and Bristol Channel. The study area, the 58 sampling sites and the arbitrary sub-divisions of the region are shown in Fig. 1. Samples were collected by means of double oblique plankton hauls and for the 3 selected months 41,57 and 58 sites respectively were sampled. Full details of the sampling method and frequency are given in Collins and Williams (1981). The zooplankton organisms were categorised as either omnivore or carnivore; each species was given a carbon value $(\mu \mathrm{g} \mathrm{C})$ based on published dry weight or carbon equivalents, or our own carbon determinations, 


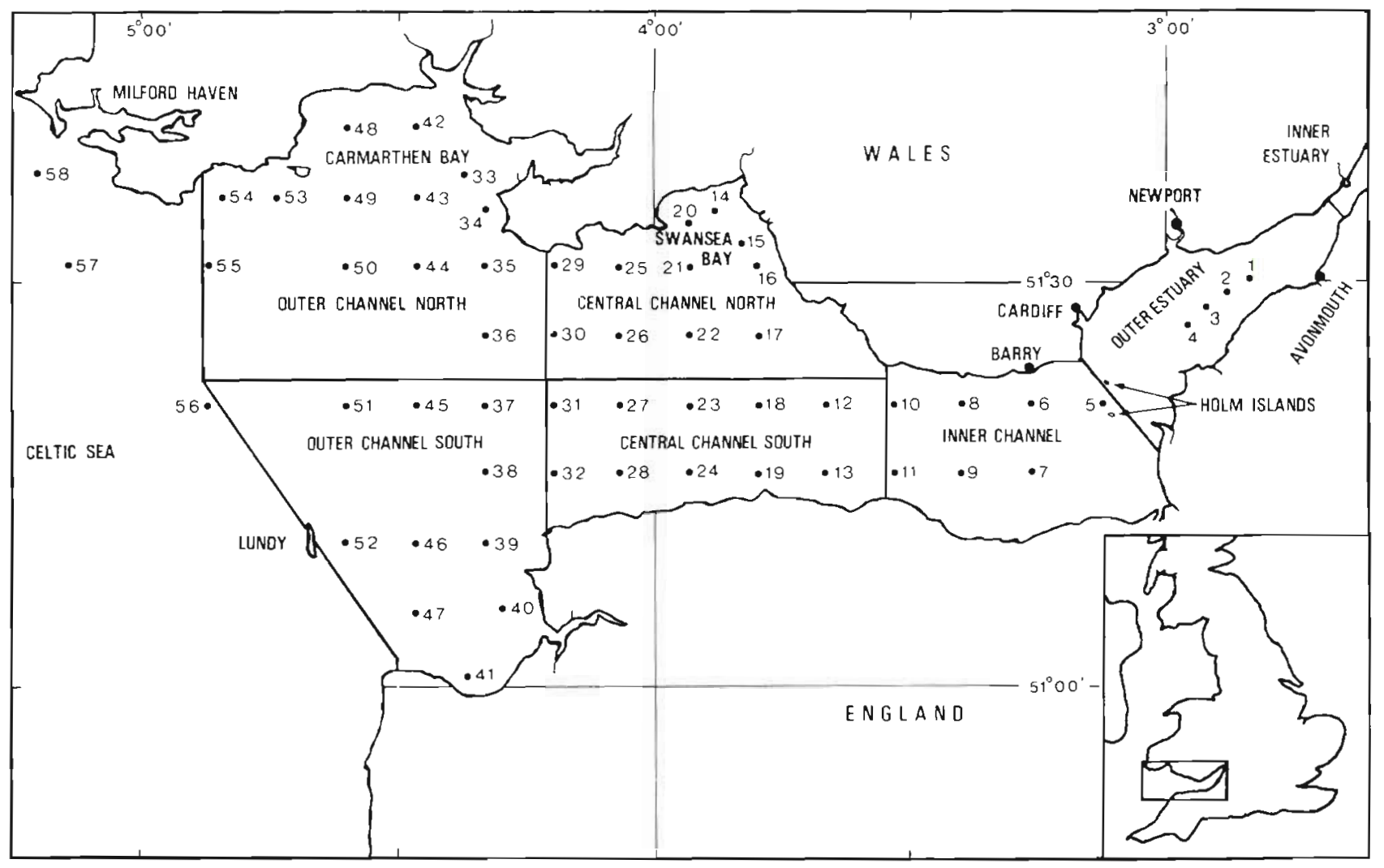

Fig. 1. Chart of Bristol Channel and Severn Estuary showing sub-regions and sampling sites (1-58)

and the mean biomass $\left(\mathrm{mg} \mathrm{C} \mathrm{m}^{-3}\right.$ ) for each trophic type calculated for the 11 surveys of the 6 regions.

Following the strategy of Field et al. (in press), sampling data were analysed using 2 objective techniques: hierarchical clustering and multi-dimensional scaling, which is an ordination method.

\section{Classification Technique}

Affinities between sampling sites and between zooplankton species were calculated for each of the 11 surveys using the program CLUSTER (Field, 1971; Field et al., in press and pers. comm.). Similarities between sampling sites were determined from species composition and numerical abundance of the zooplankton at each site. Numbers per cubic metre for each zooplankton category were double-root transformed (Field et al., 1982). A matrix of similarities was built up using the Czekanowski coefficient (Bray and Curtis, 1957; Bloom, 1981); group average sorting (Lance and Williams, 1967) was then used to erect hierarchies or dendrograms of percentage similarity (Fig. 2), The species groups or assemblages were derived in a similar way except that, instead of a double-root transformation, the original data were standardised by expressing the abundance of a species at a site as a percentage of the total abundance of that species at all sites (Field et al., 1982). Dendrograms of the zooplankton serve to cluster the species according to similarities in their geographical distributions (Fig. 3). Both sets of dendrograms for January, April and August have been redrawn to emphasise the groups, and the species in the zooplankton dendrograms have been rearranged to place the numerically dominant species at the head of each assemblage. This is an aid to interpretation and does not alter the meaning of the dendrograms.

Groups of sampling sites (Fig. 2) were associated with the clusters of zooplankton species (Fig. 3) by means of 'Shade-matrices' (Tables 1, 2 and 3). These tables show the mean abundance of each species in each group of sampling sites as a percentage of abundance of that species in all groups of sites.

\section{Ordination Technique}

Multi-dimensional scaling (MDS) analysis (Kruskal, 1977; Field et al., in press) is a method of viewing a classification. MDS has been carried out, using the same similarity matrix as for the previous clustering. 

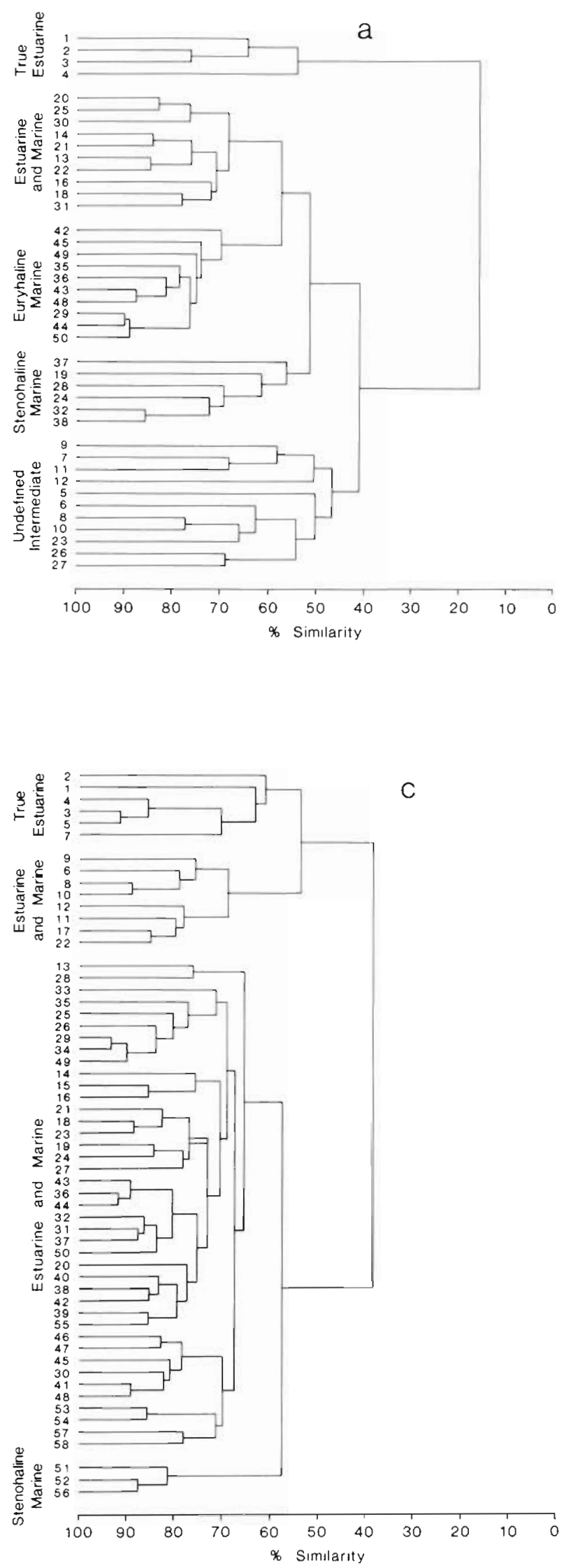

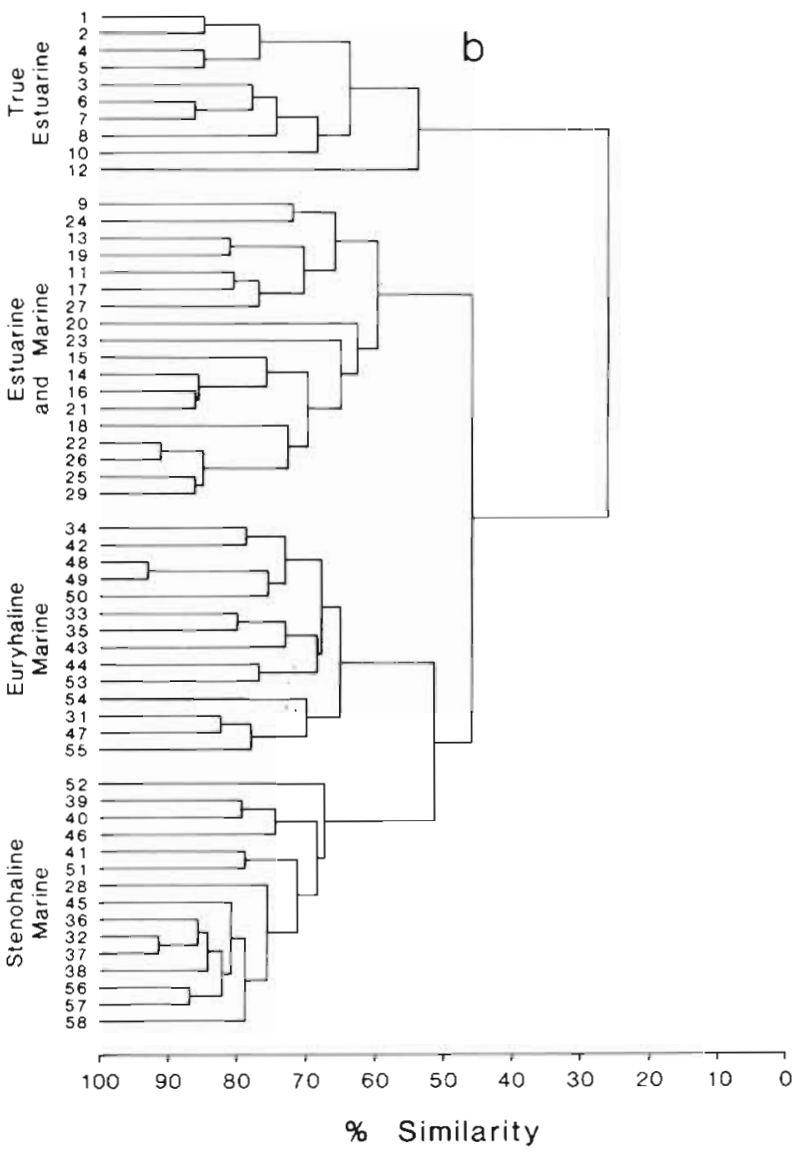

Fig. 2. Dendrograms of percentage similarity of faunal composition between the 58 sampling sites (Fig. 1) for 3 surveys in 1974; (a) January, (b) April, (c) August. Site numbers are shown on vertical axes

for sample sites and zooplankton; the results for the 3 selected months are plotted in Figs. 4 and 5. The groups derived from the dendrograms have been superimposed on the MDS plot using different symbols to identify the 4 groups. The stress factor is a measure of the stress required to force a two-dimensional (rather than higher dimensional) representation upon the similarity matrix, and values of the order of those shown in Figs. 4 and 5 indicate a fairly satisfactory two-dimensional representation (Spence and Graef, 1974). The distance between any 2 points on the plot is an increasing function of their dissimilarity; the sites or species are thus 'ordered' in the two-dimensional space in a way that is not possible using cluster analysis alone. Because the non-metric MDS uses only the rank orders of the dissimilarities, the final plot has arbitrary axes, orientation and scale. The sampling sites have been ranked for salinity using a non-linear scale starting with 1 for salinities below $27 \% \mathrm{~S}$ and rising to 9 for salinities in excess of $35 \% \mathrm{~S}$ (Fig. 4). The numbers in Fig. 5 refer to the species listed in Table 4, 

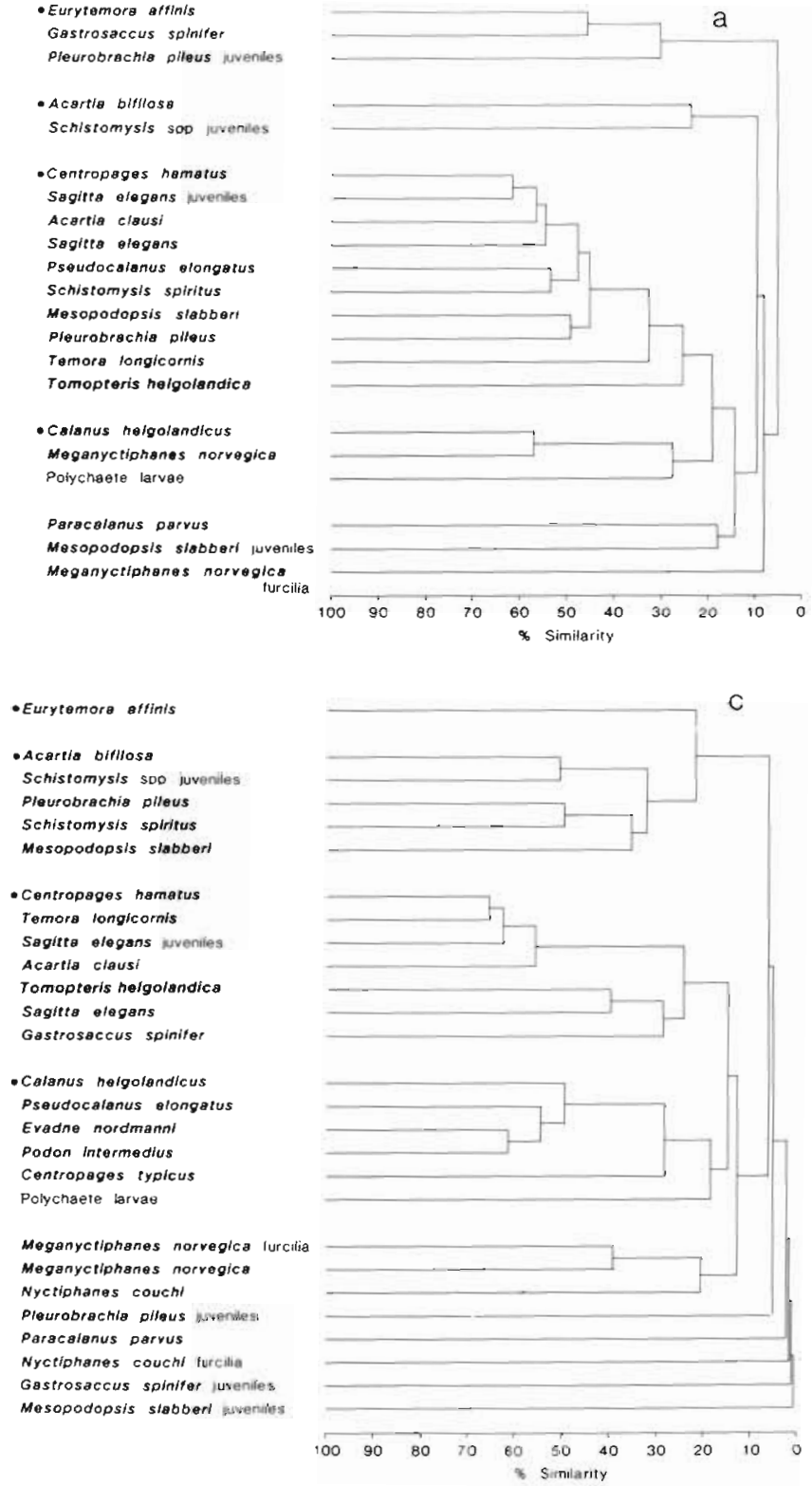

which shows the 28 holozooplankton species used for both techniques.

\section{RESULTS}

The associated groups of sampling sites and species assemblages derived from these techniques have been designated true estuarine, estuarine and marine, euryhaline marine, and stenohaline marine; they are characterised by their numerically dominant copepods: Eurytemora affinis (Poppe), Acartia bifilosa var. inermis Rose, Centropages hamatus (Lilljeborg), and Calanus helgolandicus (Claus) respectively. The distributions of these 4 faunal assemblages for January, April and August 1974 in the Outer Estuary and Bristol

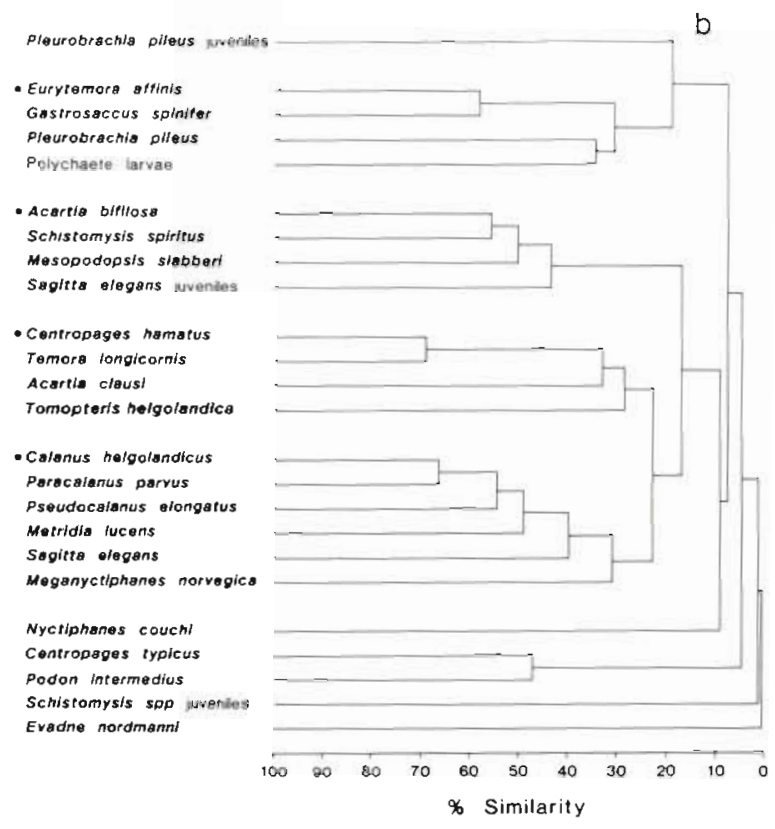

Fig. 3. Dendrograms of percentage similarity in geographical distribution between species for the 3 surveys in 1974 ; (a) January, (b) April, (c) August. Asterisk marks numerically dominant species in each of the assemblages which are, from top to bottom: true estuarine, estuarine and marine, euryhaline marine, and stenohaline marine. The bottom group in each dendrogram - plus Pleurobrachia pileus in (b) - is composed of species of low affinity

Channel are shown in Fig. 6 together with salinity isohalines.

The dendrograms of sample site similarity for April (Fig. 2b) and August (Fig. 2c) show a clear separation into 4 clusters at approximately $53 \%$ and $60 \%$ similarity respectively (there is a better than 53 or $60 \%$ similarity within each cluster or group). Five groups were separated in January at the $46 \%$ similarity level (Fig. 2a). These groups were chosen after examining the dendrogram in conjunction with the data given in Table 1 which shows a group of sampling sites that are characterised by species present at low levels of abundance. This fifth group of sites was distributed in the Inner Channel and to a limited extent in the Central Channel (Figs. 1 and 6). Strictly, this group of 'undefined' sampling sites in the January survey should be further sub-divided but was retained in the dendrogram (Fig. 2) as a mixed group. The less coherent pattern observed in January was probably the combined result of low numerical abundance of species and greater mixing of the water mass produced by increased river run-off and winter gales.

The lower similarity levels in the zooplankton dendrograms than in the site dendrograms results from the standardisation process; the clusters separate at approximately 18,29 and $19 \%$ similarity for January, 
Table 1. January 1974. Mean abundance of each species in each group of sampling sites as a percentage of the abundance of that species in all groups of sites. Percentages in bold type identify the abundant species associated with each group of sampling sites

\begin{tabular}{|c|c|c|c|c|c|}
\hline Species & $\begin{array}{c}\text { True } \\
\text { estuarine }\end{array}$ & $\begin{array}{l}\text { Estuarine } \\
\text { and marine }\end{array}$ & $\begin{array}{c}\text { Euryhaline } \\
\text { marine }\end{array}$ & $\begin{array}{l}\text { Stenohaline } \\
\text { marine }\end{array}$ & Undefined \\
\hline Eurytemora affinis & 99 & & & & 1 \\
\hline Gastrosaccus spinifer & 59 & 7 & 8 & & 26 \\
\hline Pleurobrachia pileus juveniles & 100 & & & & \\
\hline Acartia bifilosa & 1 & 95 & & & 4 \\
\hline Schistomysis spp. juveniles & & 74 & & & 26 \\
\hline Centropages hamatus & & 20 & 77 & 3 & \\
\hline Sagitta elegans juveniles & & 5 & 86 & 8 & 1 \\
\hline Acartia clausi & & 4 & 54 & 38 & 4 \\
\hline Sagitta elegans & & 20 & 64 & 11 & 5 \\
\hline Pseudocalanus elongatus & & 22 & 31 & 38 & 9 \\
\hline Schistomysis spiritus & 2 & 29 & 41 & 2 & 26 \\
\hline Mesopodopsis slabberi & & 17 & 48 & 32 & 3 \\
\hline Pleurobrachia pileus & 24 & 7 & 61 & & 8 \\
\hline Temora longicornis & & 34 & 59 & & 7 \\
\hline Tomopteris helgolandica & & 21 & 79 & & \\
\hline Mesopodopsis slabberi juveniles" & & & 65 & 35 & \\
\hline Calanus helgolandicus & & 14 & 7 & 79 & \\
\hline Meganyctiphanes norvegica & & 5 & 5 & 60 & 30 \\
\hline Polychaete larvae & & 20 & 9 & 71 & \\
\hline Meganyctiphanes norvegica furcilia & & & 17 & 69 & 14 \\
\hline Paracalanus parvus & & 8 & 24 & 18 & 50 \\
\hline
\end{tabular}

April and August, respectively. The composition of the assemblages is shown in the species dendrograms (Fig. 3). There are a number of species in Fig. 3 that have very low affinities to other species and these have been isolated in the recast dendrograms; the isolation of these species is apparent also in the multidimensional scaling plots (Fig. 5).

Besides the 4 numerically dominant copepods, the remaining copepods, mysids and chaetognath are relatively consistent in their groupings. Acartia clausi Giesbrecht, Temora longicornis (O. F. Müller) and the polychaete Tomopteris helgolandica (Greeff) were always associated with Centropages hamatus in the euryhaline marine assemblages. Pseudocalanus elongatus Boeck was in the stenohaline marine assemblage in 2 mo and the euryhaline marine in the third. Paracalanus parvus (Claus) was stenohaline marine in April but was excluded from the assemblages by CLUSTER (Fig. 3) and MDS (Fig. 5) in the other months, although the species can be associated with the undefined group in January and the euryhaline group in August (Tables 1 and 3). Centropages typicus Krøyer and Metridia lucens Boeck were stenohaline marine when present. Adults and juveniles of the most common mysid, Schistomysis spiritus (Norman) were mainly estuarine and marine; however, in January the adults were euryhaline marine and the juveniles in April were associated with the true estuarine group (Table 2) although isolated by CLUSTER and MDS. The other 2 mysids, Gastrosaccus spinifer (Goës) and Mesopodopsis slabberi (van Beneden) were less consistent in their groupings (Table 4). The adults and juveniles of the chaetognath Sagitta elegans Verrill were allocated to the euryhaline marine assemblage in January and August although in April the adults were associated with the stenohaline marine and the juveniles with the estuarine and marine assemblages; the juvenile category may have included some Sagitta setosa J. Müller.

The euphausiids in 1974 showed a temporal succession in the Bristol Channel: Meganyctiphanes novegica (M. Sars) was numerically dominant during the first half of the year followed by Nyctiphanes couchi (Bell) in the latter half. $M$. norvegica adults were assigned to the stenohaline marine assemblage in January and April by the CLUSTER program and were shown to be close to the euryhaline marine assemblage in August by the MDS program (Fig. 5). $N$. couchi was excluded by CLUSTER from all assemblages but the MDS showed that in August adults were 
Table 2. April 1974. Mean abundance of each species in each group of sampling sites as a percentage of the abundance of that species in all groups of sites. Percentages in bold type identify the abundant species associated with each group of sampling sites

\begin{tabular}{|c|c|c|c|c|}
\hline Species & $\begin{array}{c}\text { True } \\
\text { estuarine }\end{array}$ & $\begin{array}{l}\text { Estuarine } \\
\text { and marine }\end{array}$ & $\begin{array}{c}\text { Euryhaline } \\
\text { marine }\end{array}$ & $\begin{array}{c}\text { Stenohaline } \\
\text { marine }\end{array}$ \\
\hline Eurytemora affinis & 98 & 2 & & \\
\hline Gastrosaccus spinifer & 97 & 2 & & 1 \\
\hline Pleurobrachia pileus & 83 & 14 & 3 & \\
\hline Polychaete larvae & 56 & 28 & 15 & 1 \\
\hline Pleurobrachia pileus juveniles & 69 & 10 & 21 & \\
\hline Schistomysis spp. juveniles" & 100 & & & \\
\hline Acartia bifilosa & 8 & 91 & 1 & \\
\hline Schistomysis spiritus & 34 & 47 & 16 & 3 \\
\hline Mesopodopsis slabberi & 11 & 56 & 27 & 6 \\
\hline Sagitta elegans juveniles & 1 & 47 & 44 & 8 \\
\hline Evadne nordmanni & & 100 & & \\
\hline Centropages hamatus & & 25 & 72 & 3 \\
\hline Temora longicornis & & 8 & 82 & 10 \\
\hline Acartia clausi & & 2 & 48 & 50 \\
\hline Tomopteris helgolandica & & 11 & 49 & 40 \\
\hline Calanus helgolandicus & & 15 & 12 & 73 \\
\hline Paracalanus parvus & & 5 & 5 & 90 \\
\hline Pseudocalanus elongatus & 2 & 24 & 19 & 55 \\
\hline Metridia lucens & & & & 100 \\
\hline Sagitta elegans & 6 & 27 & 39 & 28 \\
\hline Meganyctiphanes norvegica & & 20 & 18 & 62 \\
\hline Nyctiphanes couchi & & & 32 & 68 \\
\hline Centropages typicus & & & & 100 \\
\hline Podon intermedius & & & & 100 \\
\hline
\end{tabular}

closely associated with the euryhaline marine assemblage (Fig. 5). The ctenophore Pleurobrachia pileus O. F. Müller was fairly ubiquitous in its distribution although it was never assigned to the stenohaline marine assemblage.

Thus, the majority of the low affinity species from the dendrograms, with the exception of the euphausiids, are isolated on the periphery of the MDS plots

The MDS plots of the sampling sites (Fig. 4) show a very tight bunching of sites belonging to each assemblage (with the obvious exception of the undefined group in January), and the symbols used in the figure serve to emphasise the agreement with the groups of sampling sites in the dendrograms shown in Fig. 2. Similarly, the species assemblages, when superimposed on the MDS species plots (Fig. 5), show the conformity of the results from the 2 techniques.

The distribution of the sampling sites in the MDS plots for the surveys carried out in January, April and August (Fig. 4) show a relationship with the salinity values measured at each site; there is an increase in the salinity values from $<27 \% \mathrm{~S}$ (top left) to $>35 \% \mathrm{~S}$ (bottom right). Ranking the sampling sites in the dendrogram for salinity would not be helpful since the order of the sites is not specific. The salinity ranges associated with the plankton assemblages for the three months are given in Table 5.

The biomass of the zooplankton $\left(\mathrm{C} \mathrm{m}^{-3}\right)$ in the 6 regions of the Bristol Channel and Severn Estuary (Fig. 1) for the 11 surveys covering the period November 1973 to February 1975 is given in Fig. 7. The chaetognath Sagitta elegans contributed the majority of the plankton carnivore biomass and was responsible for 93, 51 and $82 \%$ of the carnivore biomass in January, April and August 1974 respectively.

\section{DISCUSSION}

Using the techniques described above it has been possible to separate holozooplankton assemblages from the Bristol Channel and Severn Estuary plankton data. Four groups of species or assemblages numerically dominated by the 4 copepods Eurytemora affinis, Acartia bifilosa var. inermis, Centropages hamatus and Calanus helgolandicus were consistently extracted by 
Table 3. August 1974. Mean abundance of each species in each group of sampling sites as a percentage of the abundance of that species in all groups of sites. Percentages in bold type identify the abundant species associated with each group of sampling sites

\begin{tabular}{|c|c|c|c|c|}
\hline Species & $\begin{array}{l}\text { True } \\
\text { estuarine }\end{array}$ & $\begin{array}{l}\text { Estuarine } \\
\text { and marine }\end{array}$ & $\begin{array}{c}\text { Euryhaline } \\
\text { marine }\end{array}$ & $\begin{array}{c}\text { Stenohaline } \\
\text { marine }\end{array}$ \\
\hline Eurytemora affinis & 99 & 1 & & \\
\hline Acartia bifilosa & 46 & 54 & & \\
\hline Schistomysis spp. juveniles & 23 & 77 & & \\
\hline Pleurobrachia pileus & 53 & 28 & 19 & \\
\hline Schistomysis spiritus & 36 & 54 & 10 & \\
\hline Mesopodopsis slabberi & 15 & 73 & 12 & \\
\hline Centropages hamatus & 3 & 17 & 75 & 5 \\
\hline Temora longicornis & & 3 & 33 & 64 \\
\hline Sagitta elegans juveniles & & 5 & 49 & 46 \\
\hline Acartia clausi & 1 & 9 & 59 & 31 \\
\hline Tomopteris helgolandica & & & 100 & \\
\hline Sagitta elegans & 7 & 24 & 57 & 12 \\
\hline Gastrosaccus spinifer & 25 & 33 & 42 & \\
\hline Meganyctiphanes norvegica & 31 & 17 & 52 & \\
\hline Nyctiphanes couchi & & & 100 & \\
\hline Pleurobrachia pileus juveniles & & & 100 & \\
\hline Paracalanus parvus. & & & 100 & \\
\hline Nyctiphanes couchi furcilia. & & & 100 & \\
\hline Gastrosaccus spinifer juveniles & & & 100 & \\
\hline Mesopodopsis slabberi juveniles ${ }^{\circ}$ & & & 100 & \\
\hline Calanus helgolandicus & & & 8 & 92 \\
\hline Pseudocalanus elongatus & & 3 & 5 & 92 \\
\hline Evadne nordmanni & & & & 100 \\
\hline Podon intermedius & & & 3 & 97 \\
\hline Centropages typicus & & & 32 & 68 \\
\hline Polychaete larvae & 5 & 4 & 19 & 72 \\
\hline Meganyctiphanes norvegica furcilia ${ }^{*}$ & & & 7 & 93 \\
\hline
\end{tabular}

these techniques. These 4 assemblages conformed to the generalised classification of plankton according to salinity in estuaries (Spooner and Moore, 1940; Day, 1951; Jeffries 1967; Collins and Williams, 1981) that is (a) true estuarine, (b) estuarine and marine, (c) euryhaline marine, and (d) stenohaline marine.

Three surveys were chosen to illustrate the seasonal features of the zooplankton data and the results are consistent with those obtained from 24 surveys carried out between September 1971 and October 1975 (including the series from November 1973 to February 1975). Because of the dynamic nature of the estuarine system it is unreasonable to expect that the zooplankton fauna would conform to objective sorting techniques as discretely as the more stable faunas of terrestrial or marine benthic communities. However, the assemblages observed in January, April and August do show consistency of species composition especially for the more abundant species (Table 4). The relationships of the distribution of the numerically abundant species to salinity have been shown by Collins and Williams (1981) where salinity ranges were given as; Eurytemora affinis $<30 \% \mathrm{~S}$, Acartia bifilosa $27-33.5 \% \mathrm{~S}$, Centropages hamatus $31-35 \% \mathrm{~S}$, and Calanus helgolandicus $\geqslant 33 \% \mathrm{~S}$. These species, together with their associated faunas, make up the 4 plankton assemblages derived by the group sorting technique. The question then arises: are these assemblages just groups of independent species which occur essentially by chance having similar responses to particular environmental variables or are they communities of species interacting at various levels and composed of individuals with different trophic requirements?

The community concept in marine ecology has been reviewed by Mills (1969) who concluded that most studies showed that species were distributed along environmental gradients in more or less binomial curves of abundance, and the distribution of each species was relatively independent of others. Johnson (1970) justified the concept of communities as abstrac- 

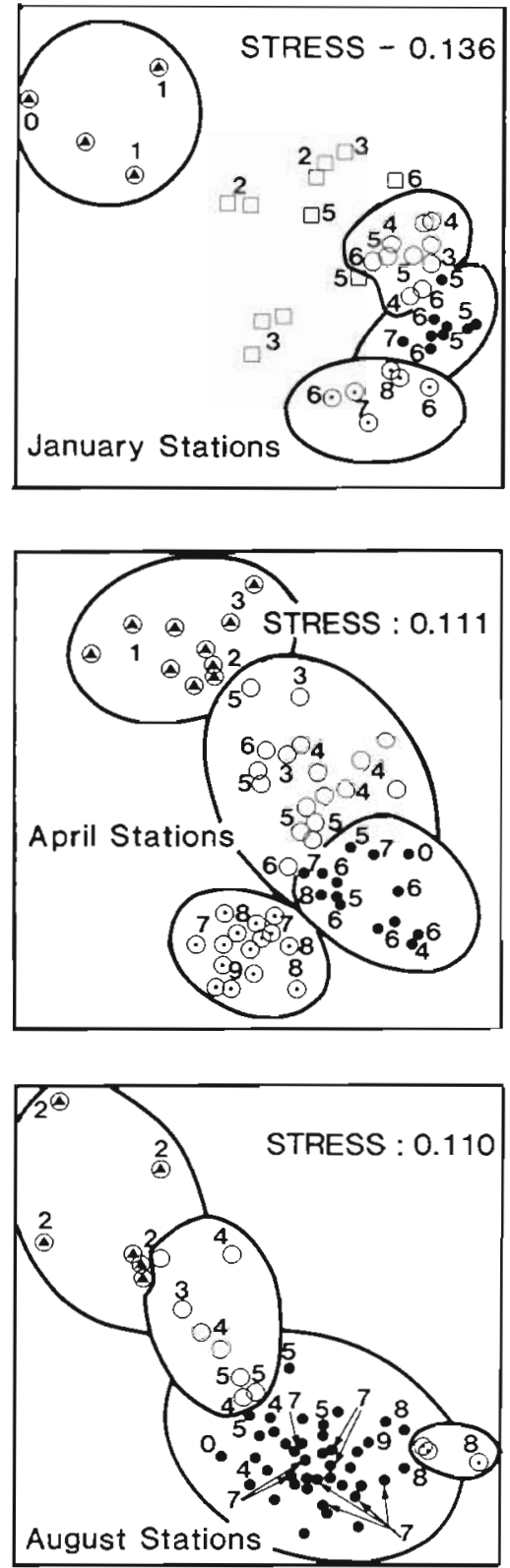

Fig. 4. Multi-dimensional scaling plots of sites for the 3 surveys in 1974. True estuarine (circle and triangle), estuarine and marine (open circle), euryhaline marine (solid circle). stenohaline marine (circle with dot) and undefined intermediate (square). The groups are taken from the dendrograms of Fig. 2. Salinities for groups of sites are shown as follows: (1) $<27$; (2) $27-<30$; (3) $30-<32$; (4) $32-<33$; (5) $33-<33.5$; (6) $33.5-<34$; (7) $34-<34.5$; (8) $34.5-<35$; (9) $\geqslant 35 \% \mathrm{~S}$; 0 : no observation. Solid circles not marked for August have salinity code 6

tions from continua while Mills (1969) suggested a practical definition of a community based on definitions proposed by Hedgpeth (1957) and Macfadyen (1963) as a'group of organisms occurring in a particular environment presumably interacting with each other
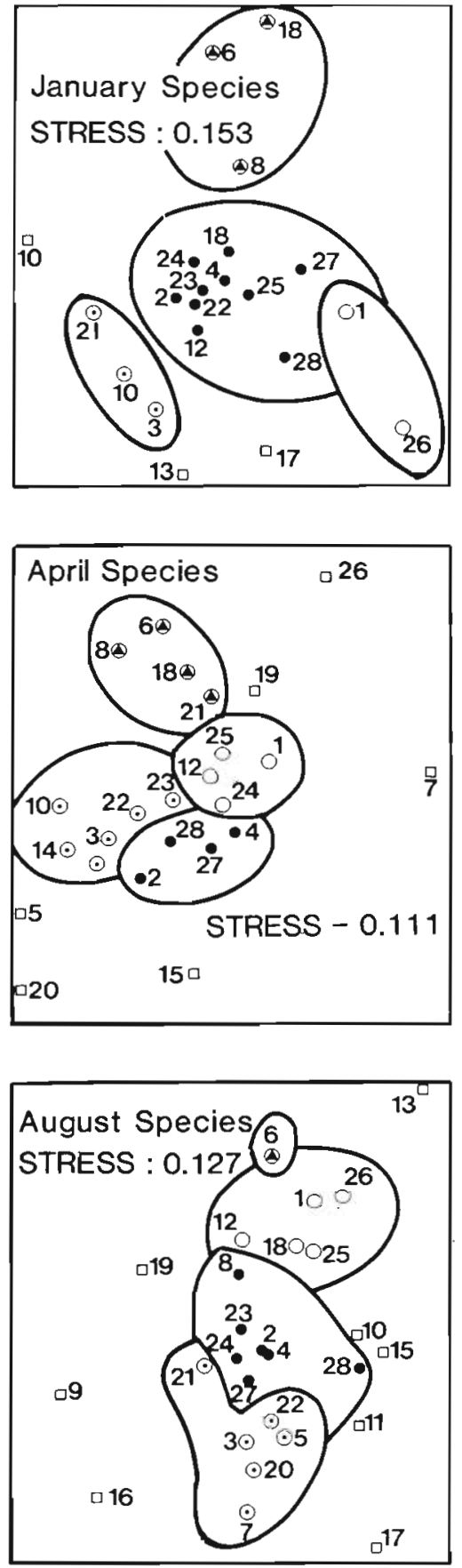

Fig. 5. Multi-dimensional scaling plots of species for the 3 surveys in 1974. Symbols have the same meaning as in Fig. 4, except that squares indicate those species having low similarities in the dendrograms (Fig. 3) from which the groups are taken. Numbers refer to species Iisted in Table 4

and with the environment and separable by means of ecological survey from other groups'.

Interaction with the environment is illustrated by the relationship of the assemblages to salinity (Fig. 4). The most obvious form of interaction between species is 
that between predator and prey. The most important predator, in terms of biomass, is Sagitta elegans which, at certain times of the year, may account for more than

Table 4. List of the 28 species used for CLUSTER and MDS Column 1: key to Fig. 5; Column 3: omnivores o, carnivores $\mathrm{C}_{\text {; }}$ Columns J (January), Ap (April), Au (August), give assemblages into which each species has been grouped; true estuarine, 1 ; estuarine and marine, 2; euryhaline marine, 3; stenohaline marine, 4. Numbers in parentheses: groupings derived from shade-matrices only

\begin{tabular}{|r|l|c|c|c|c|}
\hline 1 & \multicolumn{1}{|c|}{2} & 3 & $\mathrm{~J}$ & $\mathrm{Ap}$ & $\mathrm{Au}$ \\
\hline 1 & Accrtia bifilosa & 0 & 2 & 2 & 2 \\
2 & Acartia clousi & 0 & 3 & 3 & 3 \\
3 & Calanus helgolondicus & 0 & 4 & 4 & 4 \\
4 & Centropages homatus & c & 3 & 3 & 3 \\
5 & Centropages typicus & 0 & & $(4)$ & 4 \\
6 & Eurytemora affinis & 0 & 1 & 1 & 1 \\
7 & Evadne nordmanni & 0 & & $(2)$ & 4 \\
8 & Gastrosacus spinifer ad. & 0 & 1 & 1 & 3 \\
9 & Gastrosacous spinifer juv. & 0 & & & $(3)$ \\
10 & Meganyctiphones nomegica ad. & 0 & 4 & 4 & $(3)$ \\
11 & Meganyctiphones nomegica fur. & 0 & $(4)$ & & $(4)$ \\
12 & Mesopodopsis slabberi ad. & 0 & 3 & 2 & 2 \\
13 & Mesopodopsis slabberi juv. & 0 & $(3)$ & & $(3)$ \\
14 & Metridia lucens & 0 & & 4 & \\
15 & Nyctiphanes couchi ad. & 0 & & $(4)$ & $(3)$ \\
16 & Nyctiphanes couchi fur. & 0 & & $(3)$ \\
17 & Paracalanus pamus & 0 & & 4 & $(3)$ \\
18 & Pleurobrachia pileus ad. & c & 3 & 1 & 2 \\
19 & Pleurobrachia pileus juv. & c & 1 & $(1)$ & $(3)$ \\
20 & Podon intermedius & 0 & & $(4)$ & 4 \\
21 & Polychaete larvae & 0 & 4 & 1 & 4 \\
22 & Pseudocalanus elongatus & 0 & 3 & 4 & 4 \\
23 & Sagitta elegons ad. & c & 3 & 4 & 3 \\
24 & Sagitta elegons juv. & c & 3 & 2 & 3 \\
25 & Schistomysis spimitus ad. & 0 & 3 & 2 & 2 \\
26 & Schistonysis spimitus juv. & 0 & 2 & $(1)$ & 2 \\
27 & Temora longicomis & 0 & 3 & 3 & 3 \\
28 & Tomopteris helgolandica & 3 & 3 & 3 \\
\hline
\end{tabular}

$90 \%$ of the carnivore biomass. The copepods of the euryhaline marine assemblage, to which $S$, elegans belongs for much of the year, would form its main prey.
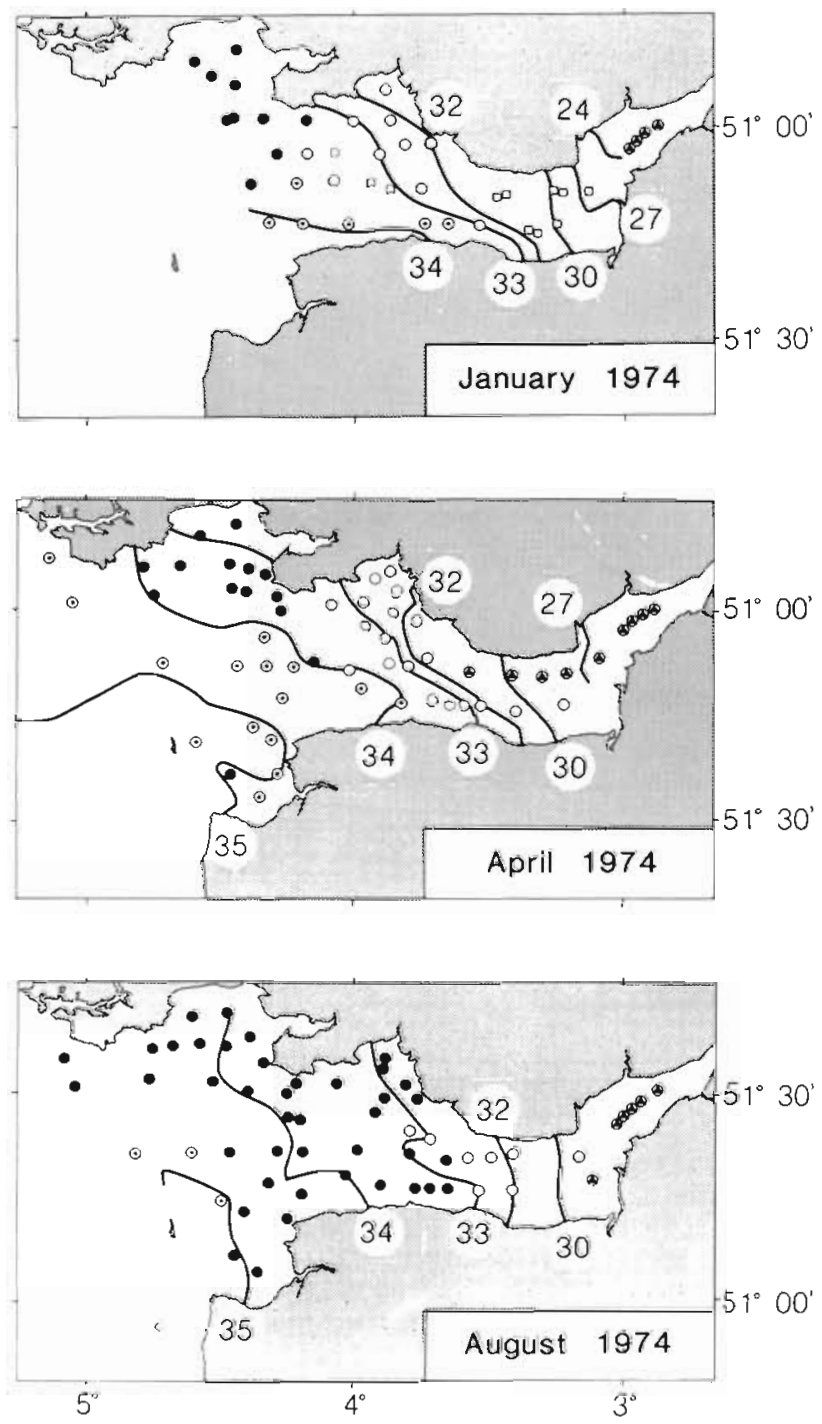

Fig. 6. Charts showing the distribution of 4 faunal assemblages for the 3 surveys in 1974. Symbols have the same meaning as in Fig. 4. Isohalines are shown at 24, 27, 30, 32, 34 and $35 \% \mathrm{~S}$

Table 5. Salinity ranges for each zooplankton assemblage for January, April and August 1974

\begin{tabular}{|c|c|c|c|c|c|}
\hline & $\begin{array}{c}\text { True } \\
\text { estuarine }\end{array}$ & $\begin{array}{l}\text { Estuarine } \\
\text { and marine }\end{array}$ & $\begin{array}{l}\text { Euryhaline } \\
\text { marine }\end{array}$ & $\begin{array}{l}\text { Stenohaline } \\
\text { marine }\end{array}$ & $\begin{array}{l}\text { Undefined } \\
\text { intermediate }\end{array}$ \\
\hline January & $<27$ & $30-<34$ & $33-<34.5$ & $>33.5^{1}$ & \multirow[t]{3}{*}{$27-<34$} \\
\hline April & $<32$ & $30-<34$ & $32-<35$ & $>34$ & \\
\hline August & $<30$ & $30-<33.5$ & $>32$ & $>34.5$ & \\
\hline
\end{tabular}



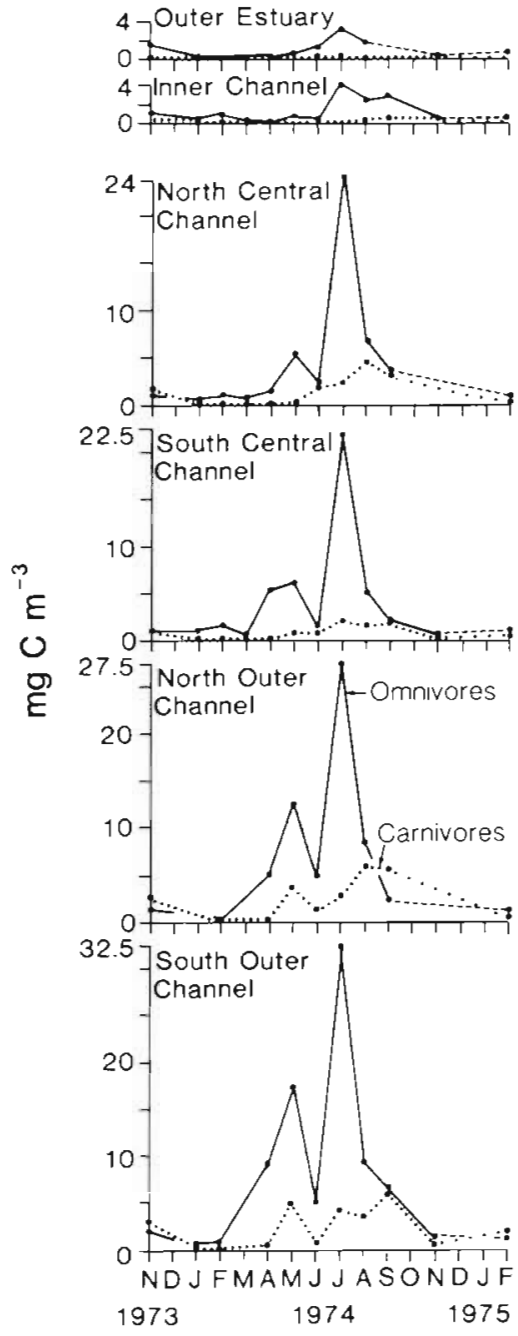

Fig. 7. Seasonal distribution of biomass ( $\mathrm{mg}$ Carbon $\mathrm{m}^{-3}$ ) in the 6 sub-regions (Fig. 1) for all omnivorous and carnivorous plankton for the period November 1973 to February 1975

Similarly the predators Pleurobrachia pileus and Tomopteris helgolandica would consume copepods and their juvenile stages in their respective assemblages. These carnivores are found in assemblages in each month, with the exception of the estuarine and marine and stenohaline marine groupings in January and the true estuarine and stenohaline marine in August. (There was, however, a large meroplankton carnivore component in August). From August onwards the predators completely dominated the biomass of the planktonic ecosystem in the Bristol Channel (Fig. 7) and were probably responsible for the rapid decline of the omnivore population.

The community concept in marine phytoplankton was discussed by Williams et al. (1981) who concluded that the underlying mechanisms for the distribution of marine diatoms in the oceans of the world were funda- mentally and generally probabilistic. We have to consider whether the responses of the zooplankton to environmental variables, such as salinity, and the plankton distributions in the estuary are either probabilistic, resulting in unstable and transient assemblages, or are the result of deterministic processes which give rise to more stable assemblages of species having ecological meaning. Results from analysing the data from 11 ecological surveys of the Bristol Channel and Severn Estuary, using multivariate techniques, show a consistency and persistence in their assemblages of holoplankton over the year; the assemblages can therefore be considered to be communities according to the criteria of Mills (1969).

Acknowledgements. We are most grateful to Dr. K. R. Clarke for valuable help with the data analysis and advice during the preparation of the manuscript. This work, which forms part of the estuarine ecology programme of the Institute for Marine Environmental Research, was partly supported by the Department of the Environment on Contract No. DGR/480/48, and is published with their permission.

\section{LITERATURE CITED}

Bloom, S. A. (1981). Similarity indices in community studies: Potential pitfalls. Mar. Ecol. Prog. Ser. 5: 125-128

Bloom, S. A., Santos, S. L., Field, J. G. (1977). A package of cumputer programs for benthic community analyses. Bull. mar. Sci. 27 (3): 577-580

Bray, J. R., Curtis, J. T. (1957). An ordination of the upland forest communities of southern Wisconsin. Ecol. Monogr. 27 (4): 325-349

Collins, N. R., Williams, R. (1981). Zooplankton of the Bristol Channel and Severn Estuary. The distribution of four copepods in relation to salinity. Mar. Biol. 64: 273-283

Day, J. H. (1951). The ecology of South African estuaries, Part 1. A review of estuarine conditions in general. Trans. R. Soc. Afr. 33: 53-91

Day, J. H., Field, J. G., Montgomery, M. (1971). The use of numerical methods to determine the distribution of the benthic fauna across the continental shelf of North Carolina. J. Anim. Ecol. 40: 93-125

Field, J. G. (1971). A numerical analysis of changes in the soft-bottom fauna along a transect across False Bay, South Africa. J. exp. mar. Biol. Ecol. 7: 215-253

Field, J. G., Clarke, K. R., Warwick, R. M. (1982). A practical strategy for analysing multispecies distribution patterns. Mar. Ecol. Prog. Ser. 8: 37-52

Hedgpeth, J. W (1957). Concepts in marine ecology. In: Hedgpeth, J. W (ed.) Treatise on marine ecology and paleoecology, Vol. 1, Ecology. The Geological Society of America. Mem. Geol. Soc. Am. 67: 29-52

Jeffries, H. P. (1967). Saturation of estuarine zooplankton by congeneric associates. In: Lauff, G. H. (ed.) Estuaries. Publs Am. Ass. Advmt Sci. 83: 500-508

Johnson, R. G. (1970). Variations in diversity within benthic communities. Am. Nat. 104: 285-300

Kruskal, J. B. (1977). Multidimensional scaling and other methods for discovering structure. In: Enslein, K., Ralston, A., Wilf, H. S. (eds.) Statistical methods for digital computers. John Wiley, New York, pp. 296-339 
Lance, G. N., Williams, W. T. (1967). A general theory of classificatory sorting strategies. I. Hierarchical systems. Comp. J. 9: 373-380

Macfadyen, A. (1963). Animal ecology, aims and methods, Sir Isaac Pitman and Sons Ltd., London

Mills, E. L. (1969). The community concept in marine zoology, with comments on contirua and instability in some marine communities: A review. J. Fish. Res. Bd Can. 26 $1415-1428$

Santos, S. L., Simon, J. L. (1974). Distribution and abundance of the polychaetous annelids in a South Florida estuary. Bull mar. Sci. 24 (3): 669-689

Shimwell, D. W. (1977). The description and classification of vegetation, Sidgwick and Jackson, London

Spence, I., Graef, J. (1974). The determination of the underly- ing dimensionality of an empirically obtained matrix of proximities. Multivar. Behav. Res. 9: 331-342

Spooner, G. M., Moore, H. B. (1940). The ecology of the Tamar estuary. VI. An account of the microfauna of the intertidal muds. J. mar. biol. Ass. U. K. 24: 283-330

Warwick, R. M., Davies, J. R. (1977). The distribution of sublittoral macrofauna communities in the Bristol Channel in relation to substrate. Estuar coast. mar Sci. 5: $267-288$

Whittaker, R. W (ed.) (1978). Classification of plant communities, Dr W. Junk b.v., The Hague

Williams, W. T., Bunt, J. S., John, R. D., Abel, D. J. (1981). The community concept and the phytoplankton. Mar. Ecol. Prog. Ser 6: 115-121

This paper was presented by Dr. J. Mauchline; it was accepted for printing on March 31, 1982 